\title{
COULD THE INTERNATIONAL HUMAN RIGHTS LAW LEAD TO CHANGES IN THE BRAZILIAN CONSTITUTION?
}

\author{
O DIREITO INTERNACIONAL DOS DIREITOS HUMANOS PODERIA LEVAR À ALTERAÇÃO \\ DA CONSTITUIÇÃO BRASILEIRA?
}

\section{Thiago Pellegrini Valverde}

Doutorando em Ciêncas Humanas e Sociais pela Universidade Federal do ABC (UFABC). Mestre em Direitos Difusos e Coletivos (subárea Direitos Humanos) pela Universidade Metropolitana de Santos (UNIMES). Bacharel em Direito pela Faculdade de Direito de São Bernardo do Campo (FDSBC - Autarquia Municipal). Avaliador dos

Cursos de Direito do Brasil junto ao MEC/SESu, nomeado por Portaria Ministerial. Professor Universitário em cursos de graduação e pós-graduação em Direito e em Relações Internacionais.

E-mail: tgpellegrini@gmail.com

\section{Wagner Wilson Deiró Gundim}

Pós Doutorando pela Mediterranea International Centre for Human Rights Research, em parceria com a Università Mediterranea di Reggio Calabria (2020-2021), com bolsa integral. Doutor em Filosofia do Direito pela Pontifícia Universidade Católica de São Paulo (PUC/SP), tendo sido bolsista CAPES. Doutorando em Direito Constitucional pela Faculdade de Direito da Universidade de São Paulo (FADUSP). Mestre em Direito Político e Econômico pela

Universidade Presbiteriana Mackenzie. Professor da Faculdade de Direito da Universidade Anhembi Morumbi. E-mail: wagner.gundim@adv.oabsp.org.br

Recebido em: 21/09/2018 Aprovado em: 29/07/2020

\begin{abstract}
This article aims to discuss the possibility of constitutional changes coming from the International Human Rights Law, both by virtue of decisions issued in the International Courts when the State has expressed adhesion, as by the international norms freely covenanted in the scenario of the international society, ratifying and internalizing them. There is a legal duty to conform internal norms to international standards for the protection of human rights, and such a duty can be carried out through constitutional change or through direct amendment of legal texts, including the constitutional text. For this purpose, what is proposed here is the adoption of a universalist and supranormative vision of human rights, aided by the control of conventionality of norms and by the abandonment of the classical view of sovereignty.
\end{abstract}

Palavras-chave: International Human Rights Law. Supranormative. Sovereignty. Conventionality Control. Judicial Review.

RESUMO: O presente artigo pretende discutir a possibilidade de modificações na Constituição Brasileira a partir do Direito Internacional dos Direitos Humanos, tanto em virtude de decisões emitidas nas Cortes Internacionais às quais o Estado tenha manifestado adesão, quanto pelas normas internacionais que livremente pactuou no cenário da sociedade internacional, ratificando e internalizando-as. Existe um dever jurídico de conformação das normas internas aos padrões 
internacionais de proteção aos direitos humanos, e tal dever pode ser levado à cabo por meio da mutação constitucional ou por alteração direta de textos legais, incluindo o texto constitucional. Para tanto, o que se propõe aqui é a adoção de uma visão universalista e supranormativa dos direitos humanos, auxiliadas pelo controle de convencionalidade das normas e pelo abandono da visão clássica de soberania.

Keywords: Direito Internacional dos Direitos humanos. Supranormatividade, Soberania. Controle de Convencionalidade. Judicial Review.

SUMÁRIO: Introduction. 1. The sovereignty and its relationship with the International Human Rights Law. 2. The fundamental rights of the human rights. 3. The supranormativity of The International Human Rights Law. 4. International Courts decisions striving for State's legislative changes: case of X and Y v. the Netherlands, European Court of Human Rights, and Olmedo Bustos et al. v. Chile ("The Last Temptation of Christ") - Inter-American Court of Human Rights. Conclusion. References.

\section{INTRODUÇÃO}

The International Law of Human Rights is a reality, especially after the United Nation`s Universal Declaration of Human Rights of 1948. This body of norms has essential importance to the civilization, because it appears as one of the most important bulwark on the protection of the rights universally recognized, which are necessary and primary to the preservation of the human beings.

At first, founded on an extremely nationalist and defensive of the internal sovereignty view, the countries of the international society used to defend that the international body of norms would not be enforceable, but only suggestive, enhancing, thus, the so called "dualist theory" of the international law, which claims the independence and distinction that exists between the international law and the internal legal order of the States.

Kelsen, in turn, from a "monist theory", defended the existence of a single legal order with projections both within the internal and international level, and because of that, due to the lack of duality between internal and international laws, the internalization of the subject of international treaties would occur automatically (ARAÚJO, 2016).

In the light of this new "monist" concept, it is worth saying, which defends the dialecticism and uniformity of the international legal order with the legal order of the countries, the international society began to accept more often the interference of the rules of international Law on a humanist vision, directed at the concretion of "fundamental human rights" 1 . A great example of this is the creation of international/regional courts for the protection of human rights, such as the InterAmerican Court of Human Rights (ACHR), which has a real inspection function on the observing the international rules.

Despite the clear evolution of the mentioned symbiosis, there are still questions that need to be solved regarding the regulatory force of the international law in the context of the internal legal order of the countries, for example: 1) what will be the regulatory status of human rights standards in the country's internal legal order? 2) is it possible that, in the case of conflict/collision between the rules of international law and the rules of a country's internal legal order, the first ones overlap with the second, even if these are endowed with constitutional status?

In the case of Brazil, the answer to the first question can be indicated under two facets. Under the current forecast of the 1988 Federal Constitution, notably in article 5, $\S 2$ and $\S 3$

\footnotetext{
1 The recognition of the existence of other normative diplomas with constitutional status outside the Constitution
} corresponding to what has been termed the "constitutionality block" (RAMOS, 2017, p. 537).

Revista de Direito Brasileira | Florianópolis, SC | v. 26 | n. 10 | p. 84-97 | Mai./Ago. 2020 
(included by constitutional amendment n. 45/2004), international treaties and conventions on human rights will be assimilated to constitutional status standards, provided that they have been approved, in each house of the National Congress, in two shifts, by three-fifths of the votes of the respective members. A contrario sensu, the treaties and conventions which do not comply with the above formal requirement, or which do not be about human rights, will not be endowed with constitutional status, but, as the current understanding of the Supreme Federal Court ${ }^{2}$, bears a "supra-legality" character, it is worth saying, are below the Constitution, but are superior to ordinary laws.

The second question presented, in turn, constitutes the problem of research in this article, whose positioning, in anticipation, advocates the possibility that standards of international law on human rights and decisions of International Courts to which countries - and, more specifically, Brazil - have adhered to, have not only mandatory observance and jurisdiction, but are also fully capable of amending internal legislation that is in disagreement with its guidelines, even the constitutional norms.

The work is divided into four chapters. In the first it presents a contemporary view of sovereignty, more appropriate to the reality of human rights, including showing that the accession of States to the treaties, pacts and declarations of international rights is the purest manifestation of sovereignty. It also points out that such standards and even decisions emanating from International Courts to which the States have freely adhered are important manifestations that complement the seriousness democratic and affirmative of the basic principles of humanity by them.

The second chapter addresses a vision that goes from fundamental rights to human rights and chooses the indistinct use of the terms or even its joint use (fundamental human rights) as well as the supra-normative conceptualization of such rights, because the human rights, contemporarily designated, arise from the evolution and expansion of the very notion of fundamental rights, produced within the States, with the historical march of claiming for rights and achieving universalization under the auspices of the International Human Rights Law, topic analyzed deeper in the third chapter.

The fourth chapter briefly analyses two paradigmatic decisions that have provided important legislative changes (and even constitutional reforms) in other States, to substantiate the position here also adopted in international jurisprudence - the cases " $X$ " and "Y" vs. Holland (European Court of Human Rights) and Olmedo Bustos vs. Chile (The Last Temptation of Christ - Inter-American Court of Human Rights).

After all the proposed analysis, the conclusion is that the disregard for the norms with supra-normative content, characteristics of those that compose the International Law of Human Rights to which States have, according to what their constitution prescribes, demonstrated acquiescence, is equivalent to the disrespecting for the dignity of the human person, which, in the Brazilian case, is the foundation of the Republic, according to express constitutional disposition. For this reason, it impels the powers of the States to the adaption with to international standards of human rights that freely have agreed.

\footnotetext{
${ }^{2}$ MAZZUOLI strongly criticizes the decision of the Federal Supreme Court, because in his view: "For many years we have defended that the international human rights treaties incorporated into the Brazilian legal order have constitutional status, independently of a majority in the National Congress, simply because we understand that such instruments have an ethical foundation that goes beyond any power that the State may have - in its reserved domain - to allocate them to previously defined "levels". Hence we have always understood that the only "level" that could have an international instrument of this nature, that is, that conveys human rights norms, was the level of constitutional norms, precisely because the latter are the highest ones within the scale hierarchy of the domestic legal order (2009, p. 1).
} 


\section{THE SOVEREIGNTY AND ITS RELATIONSHIP WITH THE INTERNATIONAL HUMAN RIGHTS LAW}

The classical notion of sovereignty dates from the sixteenth century, and the book "Les Six Livres de la République" (1576), Jean Bodin, has been doctrinally considered as the first readership to deal with the modern concept of sovereignty. Dalmo Dallari assumes that sovereignty is still seen as synonymous with independence, or as an expression of "the highest legal power" (2015, p. 90). In the Objection 11243 addressed to the Brazilian Supreme Court (Italian Republic v. President of the Federative Republic of Brazil, by reason of the extradition request of Cesare Battisti), was briefed that:

The National Sovereignty at the transnational level is based on the principle of national independence, carried out by the President of the Republic as the chief executive officer responsibilities under the art. 84, VII and VIII, of The Highest Law. The sovereignty, dichotomized into internal and external, has in the former the first manifestation of the popular will (Article 14 of the CRFB), through the people's representatives in parliament and government; in the latter, its expression at the international level through the President.

Now, if we assume that the internal sovereignty weights on the popular will expressed by the people's representatives in the parliament and government, and the external one is guided by the acts of the one who holds the position of President of the Republic. Besides, starting from the principle that in our representative democracy such position is filled by the popular majority vote, it's the President of the Republic the one who obviously binds the State to that which he/she deliberately and freely covenanted with the international society. With greater reason (by virtue of articles $1^{\circ}$, III, $3^{\circ}, \mathrm{I}, 4^{\circ} \mathrm{II}, 5^{\circ}, \S \S 2^{\circ}$ e $3^{\circ}$ of $\mathrm{CF}^{3} / 88$ and article 7 of $\mathrm{ADCT}$ ), all the international regulations about human rights, as well as every decision of International Courts that Brazil has expressed support should be linked to the State, (p.ext. internally). After all, if our President ratified an act, by the principle of good faith and the pacta sunt servanda, the State must comply it. Here, however, it is important to record that the President of the Republic is the head of State and formally held a primary competence unrelated to these issues, or the role played by the Legislative Power also assumes special relevance, especially when analyzed its function of correction, aprovation / validation and supervision according to the theory of "checks and balances".

Nowadays there is a dense international normative set of human protection, started as a strong movement from The Universal Declaration of Human Rights of 1948. Examples on sight are treaties and agreements formulated and ratified by States, including Brazil, weighing upon positivization and the universalization of a series of rights, creation of means of investigating human rights violations (through UN, Inter-American, European and African Courts), as well as determination of individual responsibilities for human rights violations (International Criminal Court) and rights recognized as being common to all mankind from the core values of human dignity. These days, as well asserts André de Carvalho Ramos, it is no longer appropriate to any State to claim the:

[...] rights of human protection as part of its reserved area" and that "eventual international investigation (even the minimal ones) of a given internal situation of human rights would offend the State sovereignty. (RAMOS, 2015, p. 123).

On their own, States can accept or not international standards; joining or not some international intergovernmental organizations. This is itself the strongest expression of sovereignty. The Permanent Court of International Justice (PCIJ) in the case S.S. Wimbledon

${ }^{3} \mathrm{CF}$ - Constituição Federal (Federal Constitution)

Revista de Direito Brasileira | Florianópolis, SC | v. 26 | n. 10 | p. 84-97 | Mai./Ago. 2020 
(judgment on 17 August 1923) ${ }^{4}$ made clear that the agreement on treaties is one of the most important acts of sovereignty by a given State.

By denying and violating fundamental human rights, the State cannot supposedly use the excuse of sovereignty. In this sense, David Held (2003, p. 169) believes that sovereignty is the political power delimited by a global basis.

The global basis refered by Held should be the International Human Rights Law. Therefrom, it's critical to set forth an interpretation of the national law in the light of the Constitution and international human rights standards. This can be done when applying what André de Carvalho Ramos names "jusfundamentalization of law" or "jusfundamental filtering", which exhorts that laws should be suitable with human rights (RAMOS, 2015, p. 371). Even constitutional supremacy undergoes changes, since it must be woven together with the international protection of human rights (Ibidem). We can no longer interpret covenanted international treaties freely, from a national perspective.

Albeit the state sovereignty's meaning comes to an autopoiesis of the politics, and with respect to the Rule of Law, an operational autonomy of the legal system (NEVES, 2008, p. 160), in fact, it evinces itself - and it is stated in the Constitution - as "the structural coupling between politics and law" (Ibidem, p. 161). State sovereignty requires from the The Rule of Law the political responsibility for critical global issues, that is a local political responsibility under the structural conditions of the world society (Ibidem, p.162). In other words, even the popular sovereignty prompts a "continuous insertion of diverse values, interests and requirements present in the pluralistic public sphere in the procedures of the Democratic State", where "political decisions (likewise constitutional decisions) and legal standards (including constitutional norms) are based on the people's sovereignty, nonsubjectively and discursively built (democracy)." (Ibidem, p. 165). We understand the International Human Rights Law is one of the most relevant factor for the pluralistic public sphere, because it sustains the defense of democracy and the most important values to the mankind. In this sense, Peter Häberle ${ }^{5}$, quoted by Alfonso Julios-Campuzano (2009, p. 103), endorses the need for a cooperative constitutional State:

[...] firmly committed to the development of its axiological content at the international level; a constitutional State model that does not renounce its direct implication for the international order and that takes its direct implication for the complex web of international relations.

This Cooperative Constitutionalism goes beyond State's borders and undermines the old concept of territorial sovereignty because it is a reachable model of a globalized world - always open to changes in an increasingly interdependent world - and running through a "collective compromise in an inter and supranational level" (Ibidem). In this sense, the International Human Rights Law should also guide this Cooperative Constitutionalism.

\section{THE FUNDAMENTAL RIGHTS OF THE HUMAN RIGHTS}

Nowadays, we see the combination of "human rights" and "fundamental rights" in "fundamental human rights" or "fundamental rights of a person" (RAMOS, 2015, p. 51). According to André de Carvalho Ramos, the merge of these terms proves that the difference between human rights "loses importance, especially in the light of a process of rapprochement and mutual relationship between the International Law and the National Law on human rights issues."

\footnotetext{
${ }^{4}$ Available in: http://www.icj-cij.org/pcij/serie_A/A_01/03_Wimbledon_Arret_08_1923.pdf.

5 "Estado constitucional cooperativo será pues aquel Estado cuya identidade incluso a nivel internacional se halla dentro de un complejo tejido de relaciones inter y supranacionales, así como en la medida en que toma plenamente conciencia de la colaboración internacional y se responsabiliza también de ella como parte de la propia solidaridad"
} (JULIOS-CAMPUZANO, 2009, p. 103).

Revista de Direito Brasileira | Florianópolis, SC | v. 26 | n. 10 | p. 84-97 | Mai./Ago. 2020 
(Ibidem, p. 51). The American Convention on Human Rights ${ }^{6}$ supports the loss of importance of the terms' distinction, given the fact that, currently, human rights have also binding force (due to the States' recognition and submission to international standards), and not only the fundamental rights preserved in constitutions and States' domestic laws.

In this line, Luigi Ferrajoli (2011, p. 9) proposes a new purely formal - or structural theoretical definition of fundamental rights:

[...] 'fundamental rights' are all those subjective legal rights that relate universally to 'all' human beings as endowed with the person's status, or citizen able to act. I understand by 'subjective right' any positive expectation (the provision) or negative (non-injury) linked to someone by a regulatory framework, and by the status of a person`s condition, in its turn, also planned by a positive Rule of law, which assumes one`s suitability as the holder of legal situations and/or the author of the acts in process.

Among the theses listed by FERRAJOLI (Ibidem, p. 16) for his formal/structural definition of fundamental rights, the one that stands out to the subject of this paper is the supranational nature of most of the fundamental rights. Many of these are:

[...] (fundamental rights) conferred by state constitutions regardless of citizenship. Especially because, after the formulation in international conventions received by state constitutions or in any form received by States, the fundamental rights become supranational rights: external and not only internal limits to the public authorities and the regulatory basis of an international democracy - far away of being active, but normatively prefigured by these rights.

Apparently, Luigi Ferrajoli treats supranational fundamental rights as part of the International Human Rights Law, which validates the importance of not making a distinction between the terminologies "human rights" and "fundamental rights." The human rights, contemporarily designed, arise from the evolution and expansion of the fundamental rights notion produced within States alongside with the march for establishing human right claims.

Samuel Moyn, supporting the thesis that human rights have been through a paradigmatic shift since The Onusiana Declaration of 1948. States that we don't even know whether the people who talked about human rights in the 40's had in mind the creation of supranational types of authority that scaffolds human rights today. Futhermore, the author affirms that:

The victorious ideology of World War II, in fact, was what I would call "national welfarism" - the commitment to update the terms of nineteenthcentury citizenship to include social protection, an obligation that was unfailingly undertaken within the terms of the nation. It was no accident that it was precisely in this era that the nation-state globalized and finally, after centuries, became the dominant political form of humanity. If human rights were resonant at all, it was as one synonym for the sorts of new entitlements States would offer their citizens: hence the Universal Declaration's self-description as a "common standard of achievement for all peoples and nations (MOYN, 2014, p. 58).

\footnotetext{
${ }^{6}$ See https://www.oas.org/dil/treaties_B-32_American_Convention_on_Human_Rights.pdf.
} 
Rights are not recognized as favors from States or economic and political elite: they are conquered by countless human sacrifices ${ }^{7}$, public opnion and social movements, as well as by the action of the economic, political and even the military forces, which, positively or negatively, were also ccrucial into their recognition. The struggle for human rights is a fight for good reason. It is a fight for the preservation of the people, all of the people, not just a few individuals or a small part of the society. Hannah Arendt (in LAFER, 1998, p. 153) says that human rights are a "constructed", an invention linked to the organization of the political community.

\section{THE SUPRANORMATIVITY OF THE INTERNATIONAL HUMAN RIGHTS LAW}

The certainty of the human rights era is that the man itself constitutes the world for the man, in the sense that he is somehow concrete. "Man does not exist because of the law but rather the law exists for the good of man" (MARX, 2014, p. 56). This is why we can talk about the human existence. People keep building. Human rights are daily builds; they are achievements in a continuous movement of progressive advances and reactionary attacks.

The major Marxist critique on the Law emphasizes that it is composed of an upper class nature, whose use of generalized commodity exchange requires, for its effectiveness, the emergence of the legal subjectivity of the principles of freedom and equality which come along with Law (ENGELS \& KAUTSKY, 2012, p. 11-12), where "a person exists only as a representative of the merchandise one has, that is, where one becomes a representative commodity of oneself" (EDELMAN, 1976, p. 95). This reasoning places the individual as the alienation's owner from the self. In spite of that, we believe Human Rights are of another ilk: "they are the essential rights and indispensable to a decent life." (Ramos, 2015: 27). Indeed, human rights have resulted from revolutionary fights, oftentimes violent ${ }^{8}$.

When it comes to Human Rights, Kant's imperative echo is clear: another person should not be treated "as simply a means to another end" (KANT, 1983, p. 36). Following the Holocaust, there is the creation of a particular kind of space, the 'camp', where people were defined as having lives not worth living, and as being vulnerable to being killed with impunity and with no law (AGAMBEN, 2015, p. 44). HABERMAS (2012a, p. 10), in the meantime, questions whether it is in The World War II's aftermath that the idea of human rights is then morally charged with the concept of human dignity. For him, the answer is no, because "the appeal to human rights feeds off the outrage of the humiliated at the violation of their human dignity" (HABERMAS, 2012b, p. 75) that has ever existed. The author speaks of human dignity as a universal concept because outrage is what informs a demand for rights, therefore, dignity works as a catalyst in the composition of human rights. Habermas states that "the background intuition of humiliation forces its way first into consciousness of suffering individuals and then into legal texts, where it finds conceptual articulation and elaboration"as new human rights (HABERMAS, 2012b, p. 78).

After all, the overarching goal of human rights is the achievement and maintenance of human beings' basic rights, and this can only be set out from the universality of human rights, yet built on diversity. HABERMAS (2012a, p. 29-30) ponders that universalist claims of human rights can only be redeemed in an all-encompassing cosmopolitan community, in a democratically established world society. Regardless of world government, democratic living governance is paramount wherefore simple and harmonious coexistence - attatched to fundamental human rights - expands upon the raison d'être of denying value superiority between different existing cultures.

\footnotetext{
${ }^{7}$ When dealing with the struggle of black Americans for the conquest of civil rights and the resulting sacrifices, ZIIN (2007, p. 76) affirms that: "White segregationists turned to violence. They exploded bombs in four black churches. They fired a shotgun through the front door of the home of Dr. Martin Luther King Jr., a minister who helped lead the boycott. But the black people of Montgomery kept up the boycott, and in November 1956the Supreme Court made segregation on local bus line illegal".

${ }^{8}$ It must be clarified here that it is not being stated that the basis of human rights established in the post second war is based on Marxism, but only that Marx, in his readings, was already aware about those issues..
}

Revista de Direito Brasileira | Florianópolis, SC | v. 26 | n. 10 | p. 84-97 | Mai./Ago. 2020 
In this regard, it was the internationalization of human rights the first step towards the idea of human rights universalization ${ }^{9}$. Consequently, the concept of universal human rights brings out the idea of supranormativity of The International Human Rights Law, since human rights break through national borders however shielded by international protection. That said, we can only witness this process by nurturing the implementation and massification of international human rights assumption. In order to ensure a real protection to human beings, both domestic and international law should not be allocated on a Tower of Babel.

According to the "Dialogue between Courts ${ }^{10}$," courts and legislatures participate in a dialogue aimed at achieving the dual control of national standards (internal constitutionality/internal conventionality and external conventionality ${ }^{11}$ ), and the suitability of domestic legislation to treaties and pacts dealt by States are the utmost measures that resulted from the human rights supranormativity. The normative superiority of Human Rights stems mostly from a jus cogens orientation, which takes laws related to Human Rights beyond their mandatory nature, onto a revoking impossibility thereof based only on particular wills. André de Carvalho Ramos prelects:

In international law, the absolute norm in the strict sense (also called peremptory norm or jus cogens norm) is the one that contains essential values for the international community as a whole, and therefore has normative superiority compared to other rules of International Law.

Hence, if a legal norm fits the jus cogens category, it does not mean it's a mandatory one, forasmuch as all of the international norms are mandatory: it means that, apart from mandatory, peremptory norm can not be changed by the will of a State. (RAMOS, 2015, p. 184-185)

The Vienna Convention on the Law of Treaties stipulates that a peremptory norm of general International Law is a norm accepted and recognized by the international community as a norm from which no derogation is permitted and the modification can be perpetrated only by a subsequent norm of general international rights of the same nature (Ibidem, p. 185). According to Norberto Bobbio,

With the 1948 Declaration [...] the assertion of rights is, at the same time, universal and positive: universal in the sense that the recipients of the principles contained therein are not only citizens of this or that State, but all men; positive in that it sets out a motion process whose human rights must be not only proclaimed or just ideally recognized. Although, they are effectively protected even against the State

\footnotetext{
${ }^{9}$ Accordingly, RAMOS argues that: "Universality was regained with the internationalization of fundamental rights " (2015, p. 207).

${ }^{10}$ The dialogue between Cortes is not a new, as it is recognized by several authors and in other countries: 1) Paraguai: SALGUEIRO, Jorge Silvero. Paraguay: diálogo entre Tribunales Nacionales e Internacionales. In: MEZZETI, Luca; CONCI, Luiz Guilherme Arcaro (Coords.). Diálogo entre cortes: a jurisprudência nacional e internacional como fator de aproximação de ordens jurídicas em um mundo cosmopolita. Brasília: OAB, Conselho Federal, 2015; 2) Reino Unido: Cf. FROSINI, Justin O. The domestic Law of the United Kingdom and Internacional and European Law: An ever more tense relationship. In: MEZZETI, Luca; CONCI, Luiz Guilherme Arcaro (Coords.). Diálogo entre cortes: a jurisprudência nacional e internacional como fator de aproximação de ordens jurídicas em um mundo cosmopolita. Brasília: OAB, Conselho Federal, 2015; e 3) Argentina: AMAYA, Jorge Alejandro. El diálogo inter-jurisdiccional entre tribunales extranjeros e internos como nueva construcción de las deciones judiciales. In: MEZZETI, Luca; CONCI, Luiz Guilherme Arcaro (Coords.). Diálogo entre cortes: a jurisprudência nacional e internacional como fator de aproximação de ordens jurídicas em um mundo cosmopolita. Brasília: OAB, Conselho Federal, 2015.

${ }^{11}$ As CAMILO (2017, p. 24) points out, in discussing the importance and the current relevance of convention control, due to the recognition of the normativity of international law in the internal ordering of countries, there was a paradigm shift in the vertical control of norms so that "compatibility in the legal system becomes not only according to the Constitution, but it gains a new parameter of adequacy, what are the human rights standards adopted at the international level, and this new form of vertical control of the legal rules" (Free Translation).
}

Revista de Direito Brasileira | Florianópolis, SC | v. 26 | n. 10 | p. 84-97 | Mai./Ago. 2020 
itself, whatever it violates them. At the end of this process, the citizens' rights will really have become, positively, on human rights. (BOBBIO, 2004, p. 29-30)

This scenario is only possible due to an ongoing change of mind (progressist) of humanity. Notwithstanding, there are side effects, such as setbacks and reactionary attacks provoked by those who persist in believing the world to be a backyard of their territories and wills. Crises cast out feelings that evoke alternative paradigms wrapped up in protection against human woes; such paradigms, that aim to protect people's dignity, are human rights - now, internationalized and supranormative ${ }^{12}$.

\section{INTERNATIONAL COURTS DECISIONS STRIVING FOR STATE'S LEGISLATIVE CHANGES: CASE OF $X$ AND Y V. THE NETHERLANDS, EUROPEAN COURT OF HUMAN RIGHTS, AND OLMEDO BUSTOS ET AL. V. CHILE ("THE LAST TEMPTATION OF CHRIST") - INTER-AMERICAN COURT OF HUMAN RIGHTS}

The chosen paradigmatic cases deal with convictions enforced by the European Court of Human Rights and the Inter-American Court of Human Rights. Both led to internal legislative amendments therein the condemned States.

X and Y v. Netherlands, 26 March 1985, is a case in which a 16-year-old mentally handicapped girl (Y) was sexually assaulted by the son-in-law (B) of the director of a privatelyrun care home in the early hours of 14 and 15 December 1977, the day after her 16th birthday. During the rape, Y had become even more mentally disturbed. Y's father, Mr. X, reported the rape to the Dutch police the day after the facts (16 December 1977). Afterwards, police reported the case to the Prosecutor's Office, where the police officer testified that Y's was unable to file a complaint independently, given her mental status. On 29 May 1978, the public prosecutor decided not to open proceedings against B, provided that he did not commit any similar offense within two years. Mr. X appealed against this decision to the Court of Appeal of Arnhem District, and on 12 June 1979, Court denied the appeal stating the victims over the age of 16 should lodge complaints of crimes themselves and, despite the police statement of Y's limitations, the law did not say whether the father could complain on the child's behalf. The Court found the protection afforded by civil law to be insufficient. However, even considering that fundamental values and essential aspects of private life were at stake, they understood that such a gap could not be filled by means

12 See Pact of San Jose, Costa Rica: https://www.oas.org/dil/treaties_B 32_American_Convention_on_Human_Rights.htm.

Article 1. Obligation to Respect Rights

1. The States Parties to this Convention undertake to respect the rights and freedoms recognized herein and to ensure to all persons subject to their jurisdiction the free and full exercise of those rights and freedoms, without any discrimination for reasons of race, color, sex, language, religion, political or other opinion, national or social origin, economic status, birth, or any other social condition.

2. For the purposes of this Convention, "person" means every human being.

Article 2. Domestic Legal Effects

Where the exercise of any of the rights or freedoms referred to in Article 1 is not already ensured by legislative or other provisions, the States Parties undertake to adopt, in accordance with their constitutional processes and the provisions of this Convention, such legislative or other measures as may be necessary to give effect to those rights or freedoms.

According to Vienna Convention on the Law of Treaties:

(see http://crossborder.ie/site2015/wp-content/uploads/2015/11/1969-Vienna-Convention-on-the-Law-ofTreaties.pdf).

Article 27. Internal law and observance of treaties

A party may not invoke the provisions of its internal law as justification for its failure to perform a treaty. This rule is without prejudice to article 46. 
of extensive interpretation. Then, facing the appeal denial of the State Supreme Court by force of Article 445 of the Code of Criminal Procedure of the Netherlands, Mr. X reached out European Commission of Human Rights (restructured by Protocol 11).

The European Court on Human Rights, upon receipt of the case, declared that it was the State's duty to adopt appropriate legislative measures to protect people in their fundamental rights in the face of violations perpetrated by individuals, claiming violation of rights based upon the Article 8 of the European Convention on Human Rights ${ }^{13}$, condemning the State by not providing legal measures of filing complaints for sexual offenses by those who are responsible for the victims, particularly in the event of vulnerable children being the victims of sexual abuse (i.e. laws insufficient for human rights' protection). Therefore, the Netherlands criminal code was inconsistent on this point with Article 8 of the European Convention of Human Rights, presenting a clear procedural gap in the law in respect of minors and the people with a mental disability, as well as whenever neglecting victims and families criminal proceedings. In this case, the State did not provide $Y$ with practical and effective protection (KILLANDER, 2010, p. 166). The State was formally condemned by the European Court of Human Rights, and was urged to prevent cases of this kind, which could only be achieved through criminal law (Ibid). During the hearings, the representative of the Netherlands government, in turn, presented a proposal for modification/adaptation of domestic legislation ${ }^{14}$ in this respect.

The case Olmedo Bustos et al. v. Chile ${ }^{15}$ is based on the ban on the showing of the film "The Last Temptation of Christ" (Martin Scorcese) by the Cinematographic Classification Council (CCC) of Chile in 1988 (year of the film`s release), at the height of the Pinochet's dictatorship.

In November 1996, when Chile had already established the democratic regime, the film was again submitted to the $\mathrm{CCC}$ by its distributors in the country. This time, it was decided to licence the film for an audience of 18 years and over. Following the approval in the same month, a group of lawyers appealed to the Court of Apelaciones del Chile to prohibit the exhibition of the film, and found result. However, in June 1997, the decision was annulled by the Supreme Court. Subsequently, in September 1997, another group of lawyers filed a complaint to the Inter-American Commission on Human Rights in the face of censorship of cinematographic product, alleging violation of the American Convention on Human Rights (Chile is a signatory State since 1990). Considering that no friendly solution could be reached out, Comission denounced Chile to the Inter-American Court of Human Rights on 15 January 1999.

During the public hearing on 18 November 2000, the Commission testified to the Court that the ban on the showing of the film "The Last Temptation of Christ" had violated Article 13 of the Convention, which determines that the exercise of the right of thought and expression shall not be subject to prior censorship. On 5 February 2001, the Court declared that Chile had to adapt their laws to the Convention's principles, resulting in allowing the showing of "The Last Temptation of Christ" with no restrictions. Likewise, Chile was found guilty of violating Article 2 of the Convention by failing to adapt their domestic law prior to the decision of the Court. Following the

\footnotetext{
${ }^{13}$ See http://www.echr.coe.int/Documents/Convention_ENG.pdf

"Right o respect for private and family life"

1. Everyone has the right to respect for his private and family life, his home and his correspondence.

2. There shall be no interference by a public authority with the exercise of this right except such as is in accordance with the law and is necessary in a democratic society in the interests of national security, public safety or the economic wellbeing of the country, for the prevention of disorder or crime, for the protection of health or morals, or for the protection of the rights and freedoms of others.

${ }^{14}$ See http://hudoc.echr.coe.int

"At the hearings, counsel for the Government informed the Court that the Ministry of Justice had prepared a Bill modifying the provisions of the Criminal Code that related to sexual offences. Under the Bill, it would be an offence to make sexual advances to a mentally handicapped person".

${ }^{15}$ See http://www.corteidh.or.cr/docs/casos/articulos/seriec 73 ing.pdf
}

Revista de Direito Brasileira | Florianópolis, SC | v. 26 | n. 10 | p. 84-97 | Mai./Ago. 2020 
outcome, Chile amended Article 19.12 of its Constitution in order to adapt it to the American Convention on Human Rights' doctrine.

Let us assume both paradigmatic cases ( $\mathrm{X}$ and $\mathrm{Y}$ v. the Netherlands and Olmedo Bustos et al. v. Chile) led the signatory States of the Convention on Human Rights (European and American) to change their domestic laws. Chile even amended its Constitution. Therefore, it's important to figure out how significant are the International Courts decisions in the field of human rights. Beth Simmons, accordingly, claims that the empowerment of human rights discussions on within the States emanates from the International Courts, as a result of their effectiveness (SIMMONS, 2009, p. 443). When we find States amending domestic legislation to conform to the dictates of the International Human Rights Law, then it gets clear the necessary path of supranormativity and the strengthening of human rights standards, particularly in democratic countries that can no longer shy away from their obligations in this affair by eclipsing behind the classic notion of sovereignty.

André de Carvalho Ramos (2015, p. 373) claims the issue of the internal standard is considered the mere fact (i.e. it expresses the will of the State) for the States and the International Courts. However, for International Law, domestic acts ought to be compatible with the previous international commitments assumed by the States, under penalty of international responsibility. The constitutional rule of a State is a mere fact whether it doesn 't entail the international legal norm (Ibidem, p. 374). As an example, Brazil does not require homologation of the foreign sentence (as provided in the Brazilian Constitution) from international courts that the country is somewhat a member due to the international body of law that governs such courts - not being state courts (Ibid, p. 375).

In this regard, the paradigmatic cases discussed in this paper only reinforce these positions. Especially in the European Court of Human Rights, there are plenty of cases ${ }^{16}$ that produced internal legislative reforms within the States party to the European Convention on Human Rights. States party to the Organization of American States acted accordingly ${ }^{17}$. Brazil, for instance, created the so-called "Maria da Penha Law" that punishes domestic violence against women after the Inter-American Commission (although not a court) publicly and internationally blaming the country for closing its eyes to violence against women; besides, the case Gomes Lund, judged by the Inter-American Court, condemned Brazil for crimes committed during the military dictatorship (1964-1985). This last case (Gomes Lund) has forced the country to create the National Commission of Truth, which aims to investigate serious human rights violations that occurred in between 18 September 1946 and 5 October 1988, even though it has so far maintained the legal effectiveness of the Amnesty Law (Law No $.6683 / 79^{18}$ ) by decision of the Supreme Court for a claim of non-compliance with a fundamental precept (ADPF $N^{\circ} .153$ ) filed by the Federal Council of the Bar Association of Brazil (OAB). In other words, it has enforced the law to conceive punishment for criminal acts committed by the agents of political repression during the military regime in Brazil; even though the Inter-American Court declared the incompatibility of the aforementioned law of amnesty to the principles of the American Convention on Human Rights. As set forth herein, the case Olmedo Bustos v. Chile, in our view, is the most emblematic of the American Convention on Human Rights to bear out the intrinsic relationship between the supranormative nature of human rights and the the International Courts decisions that, ultimately, might cause internal legislative changes in the States party to conventions created for the protection of human rights.

\footnotetext{
${ }^{16}$ Cases Belgian Linguistics (1968), Marckx (1979), Dudgeon (1981), Norris (1988), Huvig (1990), Motta (1991), Assenov (1998), Ciraklar (1998), among others.

${ }^{17}$ Cases Barrios Alto v. Peru (2001), reflecting in legislative changes in Argentina as well, when the Supreme Court of this country annulled laws No. 23.492/86 and No. 23521 /87, adopting this trial as precedent; Almonacid Arellano (2006), Aguirre Roca and others (2001), among others.

${ }^{18}$ See http://www.planalto.gov.br/ccivil_03/leis/L6683.htm
}

Revista de Direito Brasileira | Florianópolis, SC | v. 26 | n. 10 | p. 84-97 | Mai./Ago. 2020 


\section{CONCLUSION}

At the end of this paper, we drew the conclusion that the States must adapt their national legislation to the principles and doctrines of the International Human Rights Law that they freely expressed membership, because these are considered international jus cogens rules. Therefore, these standards are the true expression of States' sovereignty because, after all, when a State signs a treaty, agreement or convention, and submit itself to the jurisdiction of International Courts, it expresses its freely and unequivocally accession. One vision of absolute sovereignty, meanwhile, can no longer be used as an excuse for States' woes and mistakes, since political power is defined on a global basis, and such global basis is set out in International Human Rights Law - the one that has its core in universal human rights.

Consequently, it is entirely possible that precepts of International Human Rights Law and decisions of International Courts turn out to be the foremost guideline for domestic legislative changes. In this sense, it also seems possible that constitutional rules become unconstitutional moving forward alongside the approval of human rights treaties or the condemnation of States in International Courts, wherefrom norm incompatibility between national and international rules emerge as evident. Such is the case of the Gomes Lund case, judged by the Inter-American Court of Human Rights, which condemned Brazil internationally by declaring the incompatibility of the Brazilian Amnesty Law of 1976 in defiance of the American Convention on Human Rights. In addition, both the rules generated from original or derived Constituent Power can become unconstitutional; whether constitutional laws eventually wind up unconstitutional under International Human Rights Law, obviously infraconstitutional norms fall into line.

The adaptation of the domestic laws - the constitutional ones included - in conformity to International Human Rights Law can be performed by direct legislative amendment or judicial review $^{19}$. Likewise, legislative changes can happen by declaration of unconstitutionality and inconsistency, by reducing the laws text. At this point, it's imperative that the Legislative power performs the control of conventionality upon the control of constitutionality, promoting the "dialogue between the legislatures and the courts", which should avoid decisions that ultimately place the State as nonconformist of international decisions regarding human rights protection.

As pointed out throughout the paper, there are international paradigms that support the vision advocated here (highlighting the cases X and Y v. Netherlands and Olmedo Bustos et al. v. Chile), which show that States that have ratified Human Rights Conventions and their international jurisdiction, they have the power, but also the duty of suiting the global governance that protects universal human rights. In this respect, supranormativity urges that all the Legal Order is interpreted from a human rights perspective. Thus, a fail to comply with rules of supranormative standards is equivalent to disrespect the dignity of the human person, which is, in Brazil, the foundation of the Republic expressed through the constitutional provision.

To sum up, although the human rights protection framework from the International Human Rights Law is promising, the full realization of these rights still lacks effectiveness because it depends on more democratization of international relations and greater undertaking commitment by States (oftentimes existent only to the public opinion without been actually applied). Therefore, our response to the title of this paper is positive: yes, International Human Rights Law can lead to Constitution modification, without this meaning unconstitutionality, on the contrary.

\footnotetext{
${ }^{19}$ There are, however, issues that need to be considered regarding the applicability of the judicial review, so that the actions of the Federal Supreme Court do not become usurpation of the constituent power and violates fundamental rights, as noted by ZANOTTI and COURA (2016).
}

Revista de Direito Brasileira | Florianópolis, SC | v. 26 | n. 10 | p. 84-97 | Mai./Ago. 2020 


\section{REFERENCES}

AMAYA, Jorge Alejandro. El diálogo inter-jurisdiccional entre tribunales extranjeros e internos como nueva construcción de las deciones judiciales. In: MEZZETI, Luca; CONCI, Luiz Guilherme Arcaro (Coords.). Diálogo entre cortes: a jurisprudência nacional e internacional como fator de aproximação de ordens jurídicas em um mundo cosmopolita. Brasília: OAB, Conselho Federal, 2015.

ARAÚJO, Nadia de. Direito Internacional Privado: Teoria e Prática Brasileira. 1 ed. - Porto Alegre: Revolução eBook, 2016.

BOBBIO, Norberto. A Era dos Direitos. 9a ed. Rio de Janeiro: Elsevier, 2004.

CANÇADO TRINDADE, Antônio Augusto. "O legado da declaração universal dos direitos humanos e sua trajetória ao longo das seis últimas décadas (1948- 2008)" in GIOVANNETTI, Andrea (org). 60 anos da Declaração Universal dos Direitos Humanos. Brasília: FUNAG, 2009.

CAMILO, Guilherme Vitor de Gonzaga. A aplicação dos tratados e a doutrina do controle de convencionalidade: bases jurídicas e efetivação. Revista de Direito Brasileira. v. 17, n. 7, p. 18-39, Mai./Ago. 2017. Disponível em: <http://www.rdb.org.br/ojs/index.php/rdb/article/view/428>. Acesso em: 4 dez. 2017.

DALLARI, Dalmo de Abreu. Elementos de Teoria Geral do Estado. 32ª ed. São Paulo: Saraiva, 2015.

EDELMAN, Bernard. O direito captado pela fotografia - elementos para uma teoria marxista do direito. Coimbra: Centelha, 1976.

ENGELS, Friedrich. KAUTSKY, Karl. O socialismo jurídico. São Paulo: Boitempo, 2012.

FERRAJOLI, Luigi. Por uma Teoria dos Direitos e dos Bens Fundamentais. Porto Alegre: Livraria do Advogado, 2011.

FROSINI, Justin O. The domestic Law of the United Kingdom and Internacional and European Law: An ever more tense relationship. In: MEZZETI, Luca; CONCI, Luiz Guilherme Arcaro (Coords.). Diálogo entre cortes: a jurisprudência nacional e internacional como fator de aproximação de ordens jurídicas em um mundo cosmopolita. Brasília: OAB, Conselho Federal, 2015.

HABERMAS, Jürgen. Sobre a constituição da Europa. São Paulo: Editora Unesp, 2012(a).

HABERMAS, Jürgen. (2012b) The crisis of the European Union. Maldon, MA: Polity Press.

HELD, David. The Changing Structure of International Law: Sovereignty Transformed? Disponível em 〈https://www.polity.co.uk/global/pdf/GTReader2eHeld.pdf>, acesso em: 14 nov. 2015.

JULIOS-CAMPUZANO, Alfonso de. Constitucionalismo em tempos de Globalização. Porto Alegre: Livraria do Advogado, 2009.

Kant, I. (1993). Grounding for the metaphysics of morals: On a supposed right to lie because of philanthropic concerns. Hackett Publishing.

KILLANDER, Magnus. Interpretação dos Tratados Regionais de Direitos Humanos, in Sur. Revista Internacional de Direitos Humanos - Rede Universitária de Direitos Humanos, volume 7, número 13 jun/dez. 2010, pp. 148/175. 
LAFER, Celso A reconstrução dos direitos humanos: um diálogo com o pensamento de Hannah Arendt. São Paulo: Cia das Letras, 1988.

MARX, Karl. Crítica da filosofia do direito de Hegel. São Paulo: Boitempo, 2014.

MAZZUOLI, Valerio de Oliveira. A tese da Supralegalidade dos Tratados de Direitos Humanos. 2009. Disponível em: <http://www.lfg.com.br〉. Acesso em 01, abr. 2018.

MOYN, Samuel. The Future of Human Rights. Sur: Revista Internacional de Direitos Humanos - Rede Universitária de Direitos Humanos, v. 11, número 20 jun/dez. 2014, pp. 61/69.

NEVES, Marcelo. Entre Têmis e Leviatã: uma relação difícil. São Paulo: Martins Fontes, 2008.

RAMOS, André de Carvalho. Curso de Direitos Humanos. 4ª ed. São Paulo: Saraiva, 2017.

RAMOS, André de Carvalho. Curso de Direitos Humanos. 2a ed. São Paulo: Saraiva, 2015.

RAMOS, André de Carvalho. Processo Internacional de Direitos Humanos. $4^{\text {a }}$ ed., São Paulo: Saraiva, 2015.

RAMOS, André de Carvalho. Teoria Geral dos Direitos Humanos na Ordem Internacional. $5^{\text {a }}$ ed. São Paulo: Saraiva, 2015.

SALGUEIRO, Jorge Silvero. Paraguay: diálogo entre Tribunales Nacionales e Internacionales. In: MEZZETI, Luca; CONCI, Luiz Guilherme Arcaro (Coords.). Diálogo entre cortes: a jurisprudência nacional e internacional como fator de aproximação de ordens jurídicas em um mundo cosmopolita. Brasília: OAB, Conselho Federal, 2015.

SIMMONS, Beth. "Civil Rights in International Law: Compliance with Aspects of the International Bill of Rights” in Indiana Journal of Global Legal Studies, Vol. 16. summer 2009.

ZIIN, Howard. A Young people's history of the United States. Vol. 2. New York: Seven Stories Press, 2007.

ZANOTTI, Bruno Taufner; COURA, Alexandre de Castro. Mutação Constitucional e a Ampliação de Poderes do (e pelo) poder judiciário: reflexões acerca dos votos dos Ministros Gilmar Mendes e Eros Grau na RCL no 4335. Revista de Direito Brasileira, São Paulo, v. 14, n. 6, maio/ago, 2016. 